\title{
Heavy Metal Concentrations in Plants and Soil along Heavy Traffic Roads in North Central Nigeria
}

\section{Ogundele $\mathrm{DT}^{1 *}$, Adio $\mathrm{AA}^{2}$ and Oludele $\mathrm{OE}^{3}$}

${ }^{1}$ Department of Chemical, Geological and Physical Sciences, Kwara State University, Malete, Nigeria

${ }^{2}$ School of Allied Health and Environmental Sciences, Kwara State University, Malete, Nigeria

${ }^{3}$ Department of Industrial Safety Technology, Petroleum Training Institute, Effurun, Delta State, Nigeria

\begin{abstract}
Plant and soil samples were analyzed to determine the heavy metals ( $\mathrm{Cd}, \mathrm{Zn}, \mathrm{Cu}, \mathrm{Cr}, \mathrm{Pb}$ and $\mathrm{Ni}$ ) along major roads in Kwara State, Nigeria. Control plant and soil samples were obtained from Kwara State University (KWASU). Eight soil and plant samples were collected. One sample each of soil and plant was collected from Kwara State University as the control sample. Three plant species (Kyllinga pumila michx, Kyllinga squamulata thanm ex vahl, Cenchrus biflorus roxb) on which animals feed were collected along major roadsides. The samples were digested using wet method and heavy metals were analyzed using Atomic Absorption Spectrophotometry Technique. Lead concentration of plants from the sites was found between $24-142 \mathrm{mg} / \mathrm{kg}$ and $24-157.667 \mathrm{mg} / \mathrm{kg}$ in soil samples. Copper was found between 28.55-115.2 $\mathrm{mg} / \mathrm{kg}$ and $7.70-80.13 \mathrm{mg} / \mathrm{kg}$ in plant and soil samples respectively. Zinc ranges from $13.00-120.45 \mathrm{mg} / \mathrm{kg}$ and $30.8-$ $219.23 \mathrm{mg} / \mathrm{kg}$ in plants and soil respectively. Cadmium was between BDL-0.400 mg/kg and BDL-0.366 mg/kg in plants and soil. Chromium was detected between BDL-53.65 mg/kg and $10.57-77.10 \mathrm{mg} / \mathrm{kg}$ in plants and soil respectively. Nickel was between $1.65-11.85 \mathrm{mg} / \mathrm{kg}$ and $1.83-14.87 \mathrm{mg} / \mathrm{kg}$ in soil and plants samples. Heavy metals $(\mathrm{Cd}, \mathrm{Zn}, \mathrm{Cu}, \mathrm{Cr}$, $\mathrm{Pb}$ and $\mathrm{Ni}$ ) in the control samples were found to be $0.35,40.00,88.55,0.65,238$ and $0.65 \mathrm{mg} / \mathrm{kg}$ for Cadmium, Zinc, Copper, Chromium, Lead and Nickel in plants respectively. The soil samples were between $0.066,9.50,4.83,55.63$, $33.667,4.33 \mathrm{mg} / \mathrm{kg}$, Zinc, Copper, Chromium, Lead and Nickel respectively. Based on this study, plant and soil along road sides were found with high concentration of heavy metals.
\end{abstract}

Keywords: Heavy metals; Asomu road; Elemere road; Ganmo road; Idofian road; Jebba road; Okoloworoad; Olooru road; Shao road; Nigeria; Heavy metal pollution

\section{Introduction}

The pollution of soils by heavy metals from automobile sources is a serious environmental issue. These metals are released during different operations of the road transport such as combustion, component wear, fluid leakage and corrosion of metals. Lead, cadmium, copper, and zinc are the major metal pollutants of the roadside environments and are released from fuel burning, wear out of tyres, leakage of oils, and corrosion of batteries and metallic parts such as radiators etc. [1]. The majority of the heavy metals are toxic to the living organisms and even those considered as essential can be toxic if present in excess. The heavy metals can impair important biochemical processes posing a threat to human health, plant growth and animal life $[2,3]$. The distribution of these metals in the roadside soils is strongly but inversely correlated with the increase in the distance from road [4]. Soil is the critically environmental medium, which is subject to a number of pollutants due to different human activities [5]. The ongoing rapid economic boost has put a great burden on soil. With the increasing demand for metals during the course of industrialization and urbanization, more and more pollutants containing heavy metals has become widespread [6]. Though studies on several sources of these heavy metals accumulation in the soils are well documented, little attention has been focused on vicinities of other human activities such as wet market, mechanic workshop, dumping site, paddy field and car wash which have profound influence on the soils. For example, study of heavy metals in soil of mechanic workshops pointed out the activities performed at the mechanic workshop was mainly responsible for heavy metal contamination. The activities at the mechanic workshop generate wide varieties of wastes that are indiscriminately dumped on soils toxic metals in food stuffs, and ultimately can endanger human health. Because of its environmental significance, studies to determine risk caused by metal levels in soil on human health and forest ecosystem have attracted attention in recent years [7].

Heavy metals may be derived from many different sources to the urbanized area. One of the most important heavy metals sources is vehicle emission. Three main factors known to influence the levels in soil samples, which have been reported, are traffic, industry and weathered materials. Top soil and dusts in urban areas are indicators of heavy metal contamination from atmospheric deposition. It has been noted that location close to roads are severally polluted by heavy metals such as $\mathrm{Pb}, \mathrm{Zn}, \mathrm{Cu}, \mathrm{Cd}$, etc, from traffic [8]. These metals are toxic to human beings. Generally, the distribution of these metals is influenced by the nature of parent materials, climate and their relative mobility depending on soil parameter, such as mineralogy, texture and classification of soil.

These waste ranging from petrol, grease, oils, suspended solid, organic solvents, junked car parts contain heavy metals that may be phototoxic to plants and harmful to animals (Federal environmental Protection Agency 1991) the objective of this study was to determine the concentration of six heavy metals $(\mathrm{Cd}, \mathrm{Zu}, \mathrm{Cu}, \mathrm{Cr}, \mathrm{Pb}$ and $\mathrm{Ni})$ in soil.

*Corresponding author: Ogundele DT, Department of Chemical, Geological and Physical Sciences, Kwara State University, Malete, Nigeria, Tel: +2348034396529; E-mail: damiogundele@yahoo.com

Received September 15, 2015; Accepted October 31, 2015; Published November 04, 2015

Citation: Ogundele DT, Adio AA, Oludele OE (2015) Heavy Metal Concentrations in Plants and Soil along Heavy Traffic Roads in North Central Nigeria. J Environ Anal Toxicol 5: 334. doi:10.4172/2161-0525.1000334

Copyright: (c) 2015 Ogundele DT, et al. This is an open-access article distributed under the terms of the Creative Commons Attribution License, which permits unrestricted use, distribution, and reproduction in any medium, provided the original author and source are credited. 
Environmental pollution of heavy metal from road traffics emissions has attained much attention in the recent years due to their long-term accumulation. Several studies have proved that roadside environments are polluted by heavy metals released during different operations of the road transport. Heavy metals such as $\mathrm{Pb}, \mathrm{Cu}$, and $\mathrm{Zn}$ have been reported to be released into the atmosphere during different operations of the road transport [9].

Several studies have been done on paved roads with drains along the roads which can reduce the spread of the metals to the surrounding; the present study aims at determining the level of $\mathrm{Cd}, \mathrm{Cu}, \mathrm{Pb}, \mathrm{Ni}, \mathrm{Cr}$, in an unpaved roads and surrounding plants along major roads in North Central part of Nigeria.

\section{Materials and Methods}

The study sites are major express roads located in Kwara State. They are Asomu road, Elemere road, Ganmo road, Idofian road, Jebba road, Okolowo road, Olooru road, and Shao road. The control samples were taken from Kwara State University (KWASU).

Asomu road is located in Moro Local Government Area of Kwara State. The soil sample location lies between latitude $08^{\circ} 40.283^{\prime} \mathrm{N}$ and longitude $04^{\circ} 31.137^{\prime} \mathrm{E}$. The plant sample location lies between latitude $08^{\circ} 40.283^{\prime} \mathrm{N}$ and longitude $04^{\circ} 31.223^{\prime} \mathrm{E}$. The activity going on along this road includes farming, traders, cars and buses passing this road often with little or no traffic.

Elemere road is located in Moro Local Government Area of Kwara State. The soil sample location lies between latitude $08^{\circ} 41.159^{\prime} \mathrm{N}$ and longitude $04^{\circ} 30.845^{\prime} \mathrm{E}$, while the plant sample location lies between latitude $08^{\circ} 41.217^{\prime} \mathrm{N}$ and longitude $04^{0} 30.819^{\prime} \mathrm{E}$. the major activity on this road includes a market, garage, residential, farm including buses that ply the road.

Ganmo is a town in Ifelodun local government area of kwara state. It has a population of 206,042 by 2006 census. The soil sample collection from the road lies between latitude $08^{\circ} 25.196^{\prime} \mathrm{N}$ and longitude $04^{\circ} 36.317^{\prime} \mathrm{E}$ while the plant sample collection lies between $08^{\circ} 25.205^{\prime} \mathrm{N}$ and $05^{\circ} 36.305^{\prime} \mathrm{E}$. It is a residential area close to the market, buying and selling is the major activity along this road. Vehicles and trucks travelling out of Kwara State go through Ganmo.

Idofian is a town located in Ifelodun Local Government Area of Kwara State. The soil sample lies between latitude $08^{\circ} 22.940$ 'N and longitude $04^{\circ} 42.222^{\prime} \mathrm{E}$ while the plant sample lies between latitude $08^{\circ} 22.940^{\prime} \mathrm{N}$ and longitude $08^{\circ} 42.226^{\prime} \mathrm{E}$. Plants grow along the sample collection; a car park is also located on the same road.

Jebba road is a major road in Kwara State, where the soil sample lies between latitude $08^{\circ} 36.430^{\prime} \mathrm{N}$ and longitude $04^{\circ} 32.780^{\prime} \mathrm{E}$ while the plant sample lies between latitude $08^{\circ} 36.433^{\prime} \mathrm{N}$ and longitude $04^{\circ} 32.863^{\prime} \mathrm{N}$. Jebba road is a main road connecting the northern and southern part of Nigeria. The site has a sparsely population, with high traffic and industrial activities taking place.

Okolowo road is located in Kwara State. The soil sample lies between latitude $08^{\circ} 36.017^{\prime} \mathrm{N}$ and longitude $04^{\circ} 42.747^{\prime} \mathrm{E}$ while the plant sample lies between latitude $08^{\circ} 36.024^{\prime} \mathrm{N}$ and longitude $04^{\circ} 32.750^{\prime} \mathrm{E}$. Transportation is one of the major activities on this road.

Shao road is located in Moro Local Government Area of Kwara State. The soil sample location lies between latitude $08^{\circ} 36.433^{\prime} \mathrm{N}$ and longitude $04^{\circ} 32.863^{\prime} \mathrm{E}$. The activity on this road includes farming, school, trading and residency.
The control sample taken lies between latitude $08^{\circ} 43.487^{\prime} \mathrm{N}$ and $04^{\circ} 28.655^{\prime} \mathrm{E}$ for soil while the plant sample location lies between latitude $08^{\circ} 44.476^{\prime} \mathrm{N}$ and longitude $04^{\circ} 30.677^{\prime} \mathrm{E}$ (Table 1 ).

The soils and plants samples were collected from different locations into polythene bags. All the soils and plants samples were labeled appropriately and taken to Central Science Laboratory at Obafemi Awolowo University Ile-Ife, Osun State.

The soil samples were air dried to remove the moisture content. After drying, the samples were crushed with a clean dry mortar and pestle, and then sieved through a 2-mm sieve to fineness. $3 \mathrm{~g}$ of sieved soil samples were weighed, and then digested with a mixture of $10 \mathrm{ml}$ concentrated hydrochloric acid (HCL) and $3.5 \mathrm{ml}$ concentrated nitric acid $\left(\mathrm{HNO}_{3}\right)$. The mixtures were left overnight without heating under the switch-on fume cupboard and heated for 2 hours at $104^{\circ} \mathrm{C}$ on the next day. Distilled water was added to the digested sample and then filtered with a whatman filter paper and topped up to $100 \mathrm{ml}$ volumetric flask with distilled water. The solution was transferred into sampling bottles for analysis. Then concentration of these heavy metals in the soil samples was analyzed using a Perk-Elmer A Analyst AAS (Atomic Absorption Spectrophotometer).

The Plant samples were oven dried at $100^{\circ} \mathrm{C}$ for 24 hours and blended to fineness for easy digestion with an electrical blender and then sieved through a $2 \mathrm{~mm}$ mesh sieve for easy digestion. $5 \mathrm{ml}$ of 4:1 mixture of concentration $\mathrm{HNO}_{3}: \mathrm{HCIO}_{4}$ was added to $1 \mathrm{~g}$ of weighed plant with an analytical weighing balance. It was heated at a temperature of $105^{\circ} \mathrm{C}$ for 1 hour to dryness [10]. Then allowed to cool and made up to the mark of $50 \mathrm{ml}$ volumetric flask with $1 \mathrm{M} \mathrm{HNO}_{3}$. The solution was centrifuged using a (HARRIER 15/80 model centrifuge) for $30 \mathrm{~min}$ then transferred into sampling bottles for analysis; all digested samples were analyzed using a Perk-Elmer Analyst AAS (Atomic Absorption Spectrophotometer).

\section{Results and Discussion}

The mean concentration of cadmium, lead, copper, zinc, chromium and nickel in the plant and soil samples from the study sites and control sites are in the Tables 2-10.

Environmental samples (plants and soil) showed a wide range of values. Concentration of cadmium in the plant samples from the sites

\begin{tabular}{|c|c|c|c|}
\hline Study Area & Sample Medium & Latitude & Longitude \\
\hline \multirow{2}{*}{ Elemere } & Soil & $08^{\circ} 41.159^{\prime}$ & $04^{\circ} 30.845^{\prime}$ \\
\hline \multirow{2}{*}{ Asomu } & Plant & $08^{\circ} 41.217^{\prime}$ & $04^{\circ} 30.819^{\prime}$ \\
\hline \multirow{2}{*}{ Ganmo } & Soil & $08^{\circ} 40.541^{\prime}$ & $04^{\circ} 31.137^{\prime}$ \\
\hline \multirow{2}{*}{ Idofian } & Plant & $08^{\circ} 40.283^{\prime}$ & $04^{\circ} 31.223^{\prime}$ \\
\hline \multirow{2}{*}{ Jebba } & Soil & $08^{\circ} 25.196^{\prime}$ & $04^{\circ} 36.317^{\prime}$ \\
\hline \multirow{2}{*}{ Olooru } & Plant & $08^{\circ} 22.940^{\prime}$ & $04^{\circ} 36.305^{\prime}$ \\
\hline \multirow{2}{*}{ Okolowo } & Soil & $08^{\circ} 22.940^{\prime}$ & $04^{\circ} 42.222^{\prime}$ \\
\hline \multirow{2}{*}{ Slant } & $08^{\circ} 22.940^{\prime}$ & $04^{\circ} 42.226^{\prime}$ \\
\hline \multirow{2}{*}{ Shao } & Soil & $08^{\circ} 36.430^{\prime}$ & $04^{\circ} 32.870^{\prime}$ \\
\hline \multirow{2}{*}{ KWASU } & Plant & $08^{\circ} 36.433^{\prime}$ & $04^{\circ} 32.863^{\prime}$ \\
\hline \multirow{2}{*}{ Koil } & Plant & $08^{\circ} 39.548^{\prime} 38.436^{\prime}$ & $04^{\circ} 35.352^{\prime}$ \\
\hline \multirow{2}{*}{ Table 1: Geographical coordinates of sampling points. } \\
\hline
\end{tabular}


Citation: Ogundele DT, Adio AA, Oludele OE (2015) Heavy Metal Concentrations in Plants and Soil along Heavy Traffic Roads in North Central Nigeria. J Environ Anal Toxicol 5: 334. doi:10.4172/2161-0525.1000334

Page 3 of 5

\begin{tabular}{|c|c|c|}
\hline \multirow{2}{*}{ Parameter } & \multicolumn{2}{|c|}{$\begin{array}{c}\text { Concentration } \\
\text { Mean } \pm \text { SD }(\mathbf{m g} / \mathbf{k g})\end{array}$} \\
\hline & P1 & S1 \\
\hline $\mathrm{Cd}$ & $0.100 \pm 0.002$ & $0.033 \pm 0.003$ \\
\hline $\mathrm{Zn}$ & $59.85 \pm 0.002$ & $64.5 \pm 0.014$ \\
\hline $\mathrm{Cu}$ & $28.55 \pm 0.002$ & $16.93 \pm 0.001$ \\
\hline $\mathrm{Cr}$ & $14.1 \pm 0.029$ & $55.33 \pm 0.003$ \\
\hline $\mathrm{Pb}$ & $238 \pm 0.003$ & $27.00 \pm 0.005$ \\
\hline $\mathrm{Ni}$ & $2.45 \pm 0.003$ & $7.17 \pm 0.001$ \\
\hline
\end{tabular}

Note: Detection limit of the metal studied; Cd: $0.028 \mathrm{mg} / \mathrm{L}, \mathrm{Zn}: 0.028 \mathrm{mg} / \mathrm{L}, \mathrm{Cu}$ : $0.078 \mathrm{mg} / \mathrm{L}, \mathrm{Cr}: 0.78 \mathrm{mg} / \mathrm{L}, \mathrm{Pb}: 0.25 \mathrm{mg} / \mathrm{L}, \mathrm{Ni}: 0.125 \mathrm{mg} / \mathrm{L}$

Table 2: Concentration of heavy metal in plant and soil from Shao.

\begin{tabular}{|c|c|c|}
\hline \multirow{2}{*}{ Parameter } & \multicolumn{2}{|c|}{$\begin{array}{c}\text { Concentration } \\
\text { Mean } \pm \mathbf{S D}(\mathbf{m g} / \mathbf{k g})\end{array}$} \\
\hline $\mathrm{Cd}$ & $\mathbf{P 2}$ & $\mathbf{S 2}$ \\
\hline $\mathrm{Zn}$ & 98.028 & $0.100 \pm 0.003$ \\
\hline $\mathrm{Cu}$ & $43.30 \pm 0.004$ & $30.8 \pm 0.008$ \\
\hline $\mathrm{Cr}$ & $\mathrm{ND} \pm 0.029$ & $7.70 \pm 0.03$ \\
\hline $\mathrm{Pb}$ & $397 \pm 0.002$ & $77.10 \pm 0.062$ \\
\hline $\mathrm{Ni}$ & $2.80 \pm 0.003$ & $24 \pm 0.003$ \\
\hline
\end{tabular}

Note: Detection limit of the metal studied; Cd: $0.028 \mathrm{mg} / \mathrm{L}, \mathrm{Zn}: 0.018 \mathrm{mg} / \mathrm{L}, \mathrm{Cu}$ $0.078 \mathrm{mg} / \mathrm{L}, \mathrm{Cr}: 0.78 \mathrm{mg} / \mathrm{L}, \mathrm{Pb}: 0.25 \mathrm{mg} / \mathrm{L}, \mathrm{Ni}: 0.125 \mathrm{mg} / \mathrm{L}$. Below detection limit: $<0.028$

Table 3: Concentration of heavy metal in plant and soil from Asomu.

\begin{tabular}{|c|c|c|}
\hline \multirow{2}{*}{ Parameter } & \multicolumn{2}{|c|}{$\begin{array}{c}\text { Concentration } \\
\text { Mean } \pm \mathbf{S D}(\mathbf{m g} / \mathbf{k g})\end{array}$} \\
\hline $\mathrm{Cd}$ & $\mathbf{P 3}$ & $\mathbf{S 3}$ \\
\hline $\mathrm{Zn}$ & $117.8 \pm 0.028$ & $0.333 \pm 0.001$ \\
\hline $\mathrm{Cu}$ & $37.6 \pm 0.005$ & $219.23 \pm 2.510$ \\
\hline $\mathrm{Cr}$ & $<0.078$ & $80.13 \pm 0.007$ \\
\hline $\mathrm{Pb}$ & $142.5 \pm 0.004$ & $50.67 \pm 0.156$ \\
\hline $\mathrm{Ni}$ & $3.90 \pm 0.003$ & $97 \pm 0.001$ \\
\hline
\end{tabular}

Note: Detection limit of the metal studied; Cd: $0.028 \mathrm{mg} / \mathrm{L}, \mathrm{Zn}: 0.018 \mathrm{mg} / \mathrm{L}, \mathrm{Cu}$ : $0.078 \mathrm{mg} / \mathrm{L}, \mathrm{Cr}: 0.78 \mathrm{mg} / \mathrm{L}, \mathrm{Pb}: 0.25 \mathrm{mg} / \mathrm{L}, \mathrm{Ni}: 0.125 \mathrm{mg} / \mathrm{L}$. Below detection limit: $\mathrm{Cd}<0.028, \mathrm{Cr}<0.078$

Table 4: Concentration of heavy metal in plant and soil from Okolowo.

\begin{tabular}{|c|c|c|}
\hline \multirow{2}{*}{ Parameter } & \multicolumn{2}{|c|}{$\begin{array}{c}\text { Concentration } \\
\text { Mean } \pm \mathbf{S D}(\mathbf{m g} / \mathbf{k g})\end{array}$} \\
\hline & $\mathbf{P 4}$ & $\mathbf{S 4}$ \\
\hline $\mathrm{Cd}$ & $<0.028$ & $0.33 \pm 0.003$ \\
\hline $\mathrm{Zn}$ & $98.8 \pm 0.026$ & $68.20 \pm 0.011$ \\
\hline $\mathrm{Cu}$ & $115.2 \pm 0.006$ & $14.07 \pm 0.004$ \\
\hline $\mathrm{Cr}$ & $29.00 \pm 0.021$ & $59.30 \pm 0.103$ \\
\hline $\mathrm{Pb}$ & $24 \pm 0.001$ & $157 \pm 0.003$ \\
\hline $\mathrm{Ni}$ & $2.90 \pm 0.009$ & $7.43 \pm 0.003$ \\
\hline
\end{tabular}

Note: Detection limit of the metal studied; Cd: $0.028 \mathrm{mg} / \mathrm{L}, \mathrm{Zn}: 0.018 \mathrm{mg} / \mathrm{L}, \mathrm{Cu}$ : $0.078 \mathrm{mg} / \mathrm{L}, \mathrm{Cr}: 0.78 \mathrm{mg} / \mathrm{L}, \mathrm{Pb}: 0.25 \mathrm{mg} / \mathrm{L}, \mathrm{Ni}: 0.125 \mathrm{mg} / \mathrm{L}$. Below detection limit: $<0.028$

Table 5: Concentration of heavy metal in plant and soil from Idofian.

showed range of values ND to $0.400 \mathrm{mg} / \mathrm{kg}$ as shown in (Tables 2-10). The permissible limit of cadmium in plant recommended by WHO (1996), is $0.02 \mathrm{mg} / \mathrm{kg}$ but in almost all the plant samples were above the permissible limit. The concentration of cadmium in the soil samples from various sites were found in low range of ND to $0.36 \mathrm{mg} / \mathrm{kg}$ (Tables $2-10)$ in the soil. The maximum level of $\mathrm{Cd}$ in the soil according to the Dutch standard is $0.8 \mathrm{mg} / \mathrm{kg}$ (Table 11). Ten of the soil samples were below target values for cadmium in soil. The high concentration of $\mathrm{Cd}$ in the three plant sites P1, P6 and P8 (Tables 2, 6 and 9) may be as a result of industrial and agricultural applications. Several compounds of Cadmium are used in chemical industries and in the manufacture of pesticides, herbicides used in agriculture [11]. Cadmium is extremely toxic to human, and in particular adversely affecting kidneys, and bones [12].

\begin{tabular}{|c|c|c|}
\hline \multirow{2}{*}{ Parameter } & \multicolumn{2}{|c|}{$\begin{array}{c}\text { Concentration } \\
\text { Mean } \pm \text { SD } \mathbf{( m g / k g )}\end{array}$} \\
\cline { 2 - 3 } & P5 & S5 \\
\hline $\mathrm{Cd}$ & $<0.028$ & $0 \pm 0.004$ \\
\hline $\mathrm{Zn}$ & $93.35 \pm 0.027$ & $68.13 \pm 0.007$ \\
\hline $\mathrm{Cu}$ & $35.75 \pm 0.001$ & $8.03 \pm 0.01$ \\
\hline $\mathrm{Cr}$ & $<0.078$ & $17.16 \pm 0.038$ \\
\hline $\mathrm{Pb}$ & $25.5 \pm 0.0005$ & $17.33 \pm 0.012$ \\
\hline $\mathrm{Ni}$ & $4.45 \pm 0.008$ & $1.83 \pm 0.001$ \\
\hline
\end{tabular}

Note: Detection limit of the metal studied; Cd: $0.028 \mathrm{mg} / \mathrm{L}, \mathrm{Zn}: 0.018 \mathrm{mg} / \mathrm{L}, \mathrm{Cu}$ $0.078 \mathrm{mg} / \mathrm{L}, \mathrm{Cr}: 0.78 \mathrm{mg} / \mathrm{L}, \mathrm{Pb}: 0.25 \mathrm{mg} / \mathrm{L}, \mathrm{Ni}: 0.125 \mathrm{mg} / \mathrm{L}$. Below detection limit: $\mathrm{Cd}<0.028, \mathrm{Cr}<0.078$

Table 6: Concentration of heavy metal in plant and soil from Ganmo.

\begin{tabular}{|c|c|c|}
\hline \multirow{2}{*}{ Parameter } & \multicolumn{2}{|c|}{$\begin{array}{c}\text { Concentration } \\
\text { Mean } \pm \text { SD }(\mathbf{m g} / \mathbf{k g})\end{array}$} \\
\hline & $\mathbf{P 6}$ & $\mathbf{S 6}$ \\
\hline $\mathrm{Cd}$ & $<0.028$ & $0.100 \pm 0.002$ \\
\hline $\mathrm{Zn}$ & $23.9 \pm 0.004$ & $97.90 \pm 0.020$ \\
\hline $\mathrm{Cu}$ & $31.40 \pm 0.001$ & $36.43 \pm 0.003$ \\
\hline $\mathrm{Cr}$ & $<0.078$ & $10.57 \pm 0.026$ \\
\hline $\mathrm{Pb}$ & $24.5 \pm 0.004$ & $17.00 \pm 0.010$ \\
\hline $\mathrm{Ni}$ & $2345 \pm 0.005$ & $4.23 \pm 0.007$ \\
\hline
\end{tabular}

Note: Detection limit of the metal studied; Cd: $0.028 \mathrm{mg} / \mathrm{L}, \mathrm{Zn}: 0.018 \mathrm{mg} / \mathrm{L}, \mathrm{Cu}$ : $0.078 \mathrm{mg} / \mathrm{L}, \mathrm{Cr}: 0.78 \mathrm{mg} / \mathrm{L}, \mathrm{Pb}: 0.25 \mathrm{mg} / \mathrm{L}, \mathrm{Ni}: 0.125 \mathrm{mg} / \mathrm{L}$. Below detection limit: $<0.078$

Table 7: Concentration of heavy metal in plant and soil from Olooru.

\begin{tabular}{|c|c|c|}
\hline \multirow{2}{*}{ Parameter } & \multicolumn{2}{|c|}{$\begin{array}{c}\text { Concentration } \\
\text { Mean } \pm \text { SD (mg/kg) }\end{array}$} \\
\cline { 2 - 3 } & P7 & S7 \\
\hline $\mathrm{Cd}$ & $<0.028$ & $\mathrm{ND} \pm 0.001$ \\
\hline $\mathrm{Zn}$ & $120.45 \pm 0.061$ & $36.80 \pm 0.004$ \\
\hline $\mathrm{Cu}$ & $28.8 \pm 0.003$ & $7.7003 \pm 0.001$ \\
\hline $\mathrm{Cr}$ & $<0.078$ & $27.73 \pm 0.177$ \\
\hline $\mathrm{Pb}$ & $40.5 \pm 0.002$ & $24.33 \pm 0.001$ \\
\hline $\mathrm{Ni}$ & $1.65 \pm 0.003$ & $3.90 \pm 0.005$ \\
\hline
\end{tabular}

Note: Detection limit of the metal studied; Cd: $0.028 \mathrm{mg} / \mathrm{L}, \mathrm{Zn}: 0.018 \mathrm{mg} / \mathrm{L}, \mathrm{Cu}$ : $0.078 \mathrm{mg} / \mathrm{L}, \mathrm{Cr}: 0.78 \mathrm{mg} / \mathrm{L}, \mathrm{Pb}: 0.25 \mathrm{mg} / \mathrm{L}, \mathrm{Ni}: 0.125 \mathrm{mg} / \mathrm{L}$. Below detection limit: $\mathrm{Cd}<0.028, \mathrm{Cr}<0.078$

Table 8: Concentration of heavy metal in plant and soil from Elemere.

\begin{tabular}{|c|c|c|}
\hline \multirow{2}{*}{ Parameter } & \multicolumn{2}{|c|}{$\begin{array}{c}\text { Concentration } \\
\text { Mean } \pm \text { SD (mg/kg) }\end{array}$} \\
\cline { 2 - 3 } & P8 & S8 \\
\hline $\mathrm{Cd}$ & $0.400 \pm 0.001$ & $0.366 \pm 0.003$ \\
\hline $\mathrm{Zn}$ & $13.00 \pm 0.082$ & $144.76 \pm 0.005$ \\
\hline $\mathrm{Cu}$ & $90.75 \pm 0.003$ & $60.33 \pm 0.003$ \\
\hline $\mathrm{Cr}$ & $53.68 \pm 0.090$ & $33.17 \pm 0.127$ \\
\hline $\mathrm{Pb}$ & $37.5 \pm 0.002$ & $68 \pm 0.001$ \\
\hline $\mathrm{Ni}$ & $11.85 \pm 0.003$ & $12.33 \pm 0.001$ \\
\hline
\end{tabular}

Note: Detection limit of the metal studied; Cd: $0.028 \mathrm{mg} / \mathrm{L}, \mathrm{Zn}: 0.018 \mathrm{mg} / \mathrm{L}, \mathrm{Cu}$ $0.078 \mathrm{mg} / \mathrm{L}, \mathrm{Cr}: 0.78 \mathrm{mg} / \mathrm{L}, \mathrm{Pb}: 0.25 \mathrm{mg} / \mathrm{L}, \mathrm{Ni}: 0.125 \mathrm{mg} / \mathrm{L}$

Table 9: Concentration of heavy metal in plant and soil from Jebba. 


\begin{tabular}{|c|c|c|}
\hline \multirow{2}{*}{ Parameter } & \multicolumn{2}{|c|}{$\begin{array}{c}\text { Concentration } \\
\text { Mean } \pm \text { SD }(\mathbf{m g} / \mathbf{k g})\end{array}$} \\
\hline & $\mathbf{P 9}$ & $\mathbf{S 9}$ \\
\hline $\mathrm{Cd}$ & 0.35 & 0.066 \\
\hline $\mathrm{Zn}$ & 40.00 & 9.50 \\
\hline $\mathrm{Cu}$ & 88.85 & 4.83 \\
\hline $\mathrm{Cr}$ & 0.65 & 55.63 \\
\hline $\mathrm{Pb}$ & 238 & 33.667 \\
\hline $\mathrm{Ni}$ & 0.65 & 4.33 \\
\hline
\end{tabular}

Note: Detection limit of the metal studied; Cd: $0.028 \mathrm{mg} / \mathrm{L}, \mathrm{Zn}: 0.018 \mathrm{mg} / \mathrm{L}, \mathrm{Cu}$ : $0.078 \mathrm{mg} / \mathrm{L}, \mathrm{Cr}: 0.78 \mathrm{mg} / \mathrm{L}, \mathrm{Pb}: 0.25 \mathrm{mg} / \mathrm{L}, \mathrm{Ni}: 0.125 \mathrm{mg} / \mathrm{L}$

Table 10: Concentration of heavy metal in plant and soil from control site in KWASU.

\begin{tabular}{|c|c|c|}
\hline Elements & $\begin{array}{c}\text { *Target value of soil } \\
\text { (mg/kg) }\end{array}$ & $\begin{array}{c}* * * \text { Permissible value of } \\
\text { plant } \\
(\mathbf{m g} / \mathbf{k g})\end{array}$ \\
\hline $\mathrm{Cd}$ & 0.8 & 0.02 \\
\hline $\mathrm{Zn}$ & 50 & 0.60 \\
\hline $\mathrm{Cu}$ & 36 & 10 \\
\hline $\mathrm{Cr}$ & 100 & 1.30 \\
\hline $\mathrm{Pb}$ & 85 & 2 \\
\hline $\mathrm{Ni}$ & 35 & 10 \\
\hline
\end{tabular}

*Target values are specified to indicate desirable maximum levels of elements in unpolluted soils

Source: Denneman and Robberse 1990; Ministry of Housing, Netherlands 1994 ${ }^{* *}$ Source: WHO (1996)

Table 11: WHO permissible limits for heavy metals in plant and soil.

\begin{tabular}{|c|c|}
\hline Botanical Name & Family \\
\hline Kyllinga pumila michx & Cyperaceae \\
\hline Kyllinga squamulata thanm ex Vahl & Cyperaceae \\
\hline Cenchrus biflorus roxb & Poaeceae \\
\hline
\end{tabular}

Table 12: Botanical names of the Plant samples and their families

Coppers concentration in plants ranged between 28.55 to $115.2 \mathrm{mg} /$ $\mathrm{kg}$ (Tables 2-10). The permissible limit according to WHO standard (1996) is $10 \mathrm{mg} / \mathrm{kg}$. All the plant samples exceeded the copper standard $(10 \mathrm{mg} / \mathrm{kg})$. The soil concentration of $\mathrm{Cu}$ was between the ranges 4.83 $80.13 \mathrm{mg} / \mathrm{kg}$ (Tables 2-10), the permissible limit recommended by Dutch standard is $36 \mathrm{mg} / \mathrm{kg}$. The high value of $\mathrm{Cu}$ in the soil was much higher in site S5, S6 and S8 with 80.13 , and $60.33 \mathrm{mg} / \mathrm{kg}$ respectively (Tables 6, 7 and 9). Copper is a micro element which is essential in plant growth and occurs generally in soil, sediments and air. $\mathrm{Cu}$ content has been reported to differ according to the soil type and pollution source [13]. The high concentration in some sites may be as a result of burnt vehicles along the major roads because copper is commonly found in electrical wirings.

Tables 2-10 show that the values of chromium in the plant samples in some of the sites were not detected, while P1, P4 and P8 (Tables 2, 5 and 9) were found to be greater than the permissible limit which is 1.30 $\mathrm{mg} / \mathrm{kg}$ recommended by WHO 1996 (Table 11). The concentration of chromium in the soil was found in the range of 10.57 to $77.10 \mathrm{mg} / \mathrm{kg}$, permissible limit recommended by Dutch standard is $100 \mathrm{mg} / \mathrm{kg}$ for chromium. All the soil samples were within the permissible limit. The higher concentration in the plant may be as a result of the different kinds of Chromium that differ in their effects and upon which they enter air, water and the soil. $\mathrm{Cr}^{3+}$ and $\mathrm{Cr}^{6+}$ form through natural processes and human activities. Chromium is not essential for plant growth, it was not detected in some plant sites due to the fact that uptake of $\mathrm{Cr}$ by plant shoot is generally low [14].
The concentration of $\mathrm{Ni}$ in plant in all sites varied between 1.65$11.85 \mathrm{mg} / \mathrm{kg}$. The permissible limit by WHO 1996 (Table 11) is 10 $\mathrm{mg} / \mathrm{kg}$, the concentration values were all within the permissible limit except P8 (Table 9) which was higher than recommended limit. The concentration on $\mathrm{Ni}$ in soil samples was between $1.83-14.87 \mathrm{mg} / \mathrm{kg}$. Recommended limit for Ni by WHO 1996 is $35 \mathrm{mg} / \mathrm{kg}$ (Table 11). The sample was below this recommended limit so it is concluded that plants are safe from the hazardous effects of Nickel. Nickel has been considered to be an essential trace element for human and animal health. $\mathrm{Ni}$ is absorbed easily and rapid by plant [15]. According to ref. [13] airborne particles emitted by brakes and wears from vehicles tyres can contain considerable amounts of $\mathrm{Ni}$.

The level of lead in plant samples from the sites varied widely from 24-397 mg/kg (Tables 2-9), compared to the permissible limit for plants recommended by WHO which is $2 \mathrm{mg} / \mathrm{kg}$ as shown in (Table 11). The concentration in the soil samples from sites also varied widely from $24-157.667 \mathrm{mg} / \mathrm{kg}$. The Dutch limit of Lead is $85 \mathrm{mg} / \mathrm{kg}$ (Table 11), values of both plant and soil were extremely high and exceeded these recommended limits. The high concentration depicts the environment is polluted due to human activities such as fuel combustion and vehicular emissions because of the heavy traffic on this roads. Lead has toxic properties and is found in large amounts in many electronic devices (Nordic council of ministers, 1995), it is a major constituent of lead-acid battery extensively in car batteries and tyres which can end up in soil through corrosion.

In this study, $\mathrm{Zn}$ concentration from the plants sites varied between $23.9-117.8 \mathrm{mg} / \mathrm{kg}$ (Tables 2-9), and WHO's permissible limit is 0.60 $\mathrm{mg} / \mathrm{kg}$ (Table 11). The concentration of $\mathrm{Zn}$ from the soil sites varies widely between $30.8-219.23 \mathrm{mg} / \mathrm{kg}$ (Tables 2-9) and the recommended limit by WHO 1996 is $50 \mathrm{mg} / \mathrm{kg}$ (Tables 10-12). Almost all the ventures exhibited very high concentration compared to its permissible limit. $\mathrm{Zn}$ is used in brake linings because of their heat conducting properties and as such released during mechanical abrasion of vehicles, and from engine oil combustion and tyres of motor vehicle [15-17]. The concentration may be as a result of the number of trucks and emissions that pass through these roads.

\section{$\mathrm{Cd}, \mathrm{Zn}, \mathrm{Cu}, \mathrm{Cr}, \mathrm{Pb}$ and $\mathrm{Ni}$ in soil and plant samples of the studied area}

The concentration of $\mathrm{Cd}, \mathrm{Zn}, \mathrm{Cu}, \mathrm{Cr}, \mathrm{Pb}$ and $\mathrm{Ni}$ of soil and plant samples are given in Tables 2-9. All the soil and plant samples analyzed indicated high level than the normal value $(2 \mathrm{mg} / \mathrm{kg}$ and $85 \mathrm{mg} / \mathrm{kg})$ (WHO 1996) $\mathrm{Pb}$ respectively, agreeing to the contamination of the sites may be an attribute of high level of traffic and vehicular emission on Idofian, Okolowo and Jebba road.

The concentration of $\mathrm{Zn}$ in soil ranged from 30.8 to $144.7 \mathrm{mg} / \mathrm{kg}$ for all the sites with Jebba road having the highest concentration. Plant samples have a range of $\mathrm{Zn}$ from 13.00 to $120.45 \mathrm{mg} / \mathrm{kg}$. $\mathrm{Zn}$ is higher in soil and plant than the detection limit which is $50 \mathrm{mg} / \mathrm{kg}$ and 0.60 $\mathrm{mg} / \mathrm{kg}[18]$.

The values of $\mathrm{Cu}$ in soil range from $7.70-60.33 \mathrm{mg} / \mathrm{kg}$ and $28.55-$ $115.2 \mathrm{mg} / \mathrm{kg}$ in plant. Some of the plant and soil sample range below detection limit while others were higher as shown in Idofian and Asomu. The concentration of $\mathrm{Ni}$ in plant samples from the site varied from $1.65-11.85 \mathrm{mg} / \mathrm{kg}$. Within the permissible limit except P8 Table 9 which were higher than recommended limit. The concentration of $\mathrm{Ni}$ in soil sample was between $1.83-14.87 \mathrm{mg} / \mathrm{kg}$. Ni in normal plant and soil are within $10 \mathrm{mg} / \mathrm{kg}$ and $35 \mathrm{mg} / \mathrm{kg}$ respectively. 
Citation: Ogundele DT, Adio AA, Oludele OE (2015) Heavy Metal Concentrations in Plants and Soil along Heavy Traffic Roads in North Central Nigeria. J Environ Anal Toxicol 5: 334. doi:10.4172/2161-0525.1000334

The values of $\mathrm{Cr}$ in the plant samples were not detected while $\mathrm{P} 1$, $\mathrm{P} 4$, and $\mathrm{P} 8$ were found to be greater than permissible limit of $1.30 \mathrm{mg} /$ $\mathrm{kg}$ [18]. The concentration of $\mathrm{Cr}$ in the soil were found in the range of $10.57-77.10 \mathrm{mg} / \mathrm{kg}$, target value recommended by Dutch standard is $100 \mathrm{mg} / \mathrm{kg}$ all the soil samples were within the target values.

The concentration of $\mathrm{Cd}$ in soil and plant samples was not detected in majority of the sites. The concentration of Cd in the soil sample from various sites was found between ND to $0.366 \mathrm{mg} / \mathrm{kg}$. Permissible level of Cd in soil by Dutch standard is $0.8 \mathrm{mg} / \mathrm{kg}$.

\section{Conclusion}

Heavy metal content in different sites varied significantly in the plant and soil samples therefore consumption of food sold along road sides should be discourage. Also drying of edible food on tarred roads in rural and urban community should be discouraged. Agricultural farms should not be close to highways to prevent excessive buildup of heavy metals.

\section{References}

1. Dolan LMJ, Van Bohemen H, Whelan P, Akbar KF, Omalley V, et al. (2006) Towards The Sustainable Development Of Modern Road Ecosystem. The Ecology of Transportation: Managing Mobility for the Environment 10: 275-331.

2. Järup L, Hellström L, Alfvén T, Carlsson MD, Grubb A, et al. (2000) Low level exposure to cadmium and early kidney damage: the OSCAR study. Occup Environ Med 57: 668-672.

3. Khan R, Isradi SH, Ahmad H, Mohan A (2005) Heavy metal pollution Assessment in surface water bodies and its suitability for irrigation around the Neyevli Lignite mines and associated industrial complex, Tamil Nadu, India. Mine Water and the environ 24: 151-161.

4. Warren RS, Birch P (1987) Heavy metal levels in atmospheric particulates, roadside dust and soil along a major urban highway. Science of Total Environment 59: 233-256.

5. Al-Khashman OA, Shawabkeh RA (2006) Metals distribution in soils around the cement factory in southern Jordan. Environ Pollut 140: 387-394.
6. Yang Z, Lu W, Long Y, Bao X, Yang Q (2011) Assessment of heavy metals contamination in urban topsoil from Changchun City, China. Journal of Geochemical Exploration 108: 27-38.

7. Denti B, Cocucci SM, Di Givolamo F (1998) Environmental pollution and forest stress: a multidisciplinary approach study on alpine forest ecosystems. Chemosphere 36: 1049-1054.

8. Wilson B, Lang B, Pyatt FB (2005) The dispersion of heavy metals in the vicinity of Britannia Mine, British Columbia, Canada. Ecotoxicol Environ Saf 60: 269 276.

9. Zhang F, Yan X, Zeng C, Zhang M, Shrestha S, et al. (2012) Influence of Traffic Activity on Heavy Metal Concentrations of Roadside Farmland Soil in Mountainous Areas. International Journal of Environmental Research and Public Health 9: 1715-1731.

10. Kakulu SE, Jacob JO (2006) Comparison of digestion methods for Trace meta Determination in moss samples. Proceeding of the 1st National Conference of the Faculty of Science, University of Abuja pp 77-81.

11. Alloway BJ, Ayres DC (1998) Chemical Principle of Environmental Pollution Water, Air, and Soil Pollution 102: 216-218.

12. Greenpeace (2008) Toxic tech. Not in our Backyard, Uncovering the hidden flows of e-waste, Greenpeace International, Amsterdam, USA.

13. Onder S, Dursun S, Gezgin S, Demirbas (2007) Determination of heavy metals pollution in Grass and soil of city centre Green Area (Konya Turkey). Pol J Environ stud 1: 145-154.

14. Hoffman RD, Curnow RD (1973) Toxic heavy metals in Lake Erie herons. Proc Conf Great Lakes Res 16: 50-53.

15. Hjortenkrans D (2003) Diffuse metal emission to air from road traffic. A case study of Kalmar, Sweden. Environ Sci Sect Bullet, pp: 1-55.

16. El-Gamal IM (2000) Distribution pattern of some heavy metals in the soil and plants along EL-Moukattam highway, Egypt. ICEHM 518-524.

17. Dolan MS, Clapp CE, Allmaras RR, Baker JM, Molina JAE (2006) Soil organic carbon and nitrogen in a Minnesota soil as related to tillage, residue and nitrogen management. Soil Tillage \& Research 89: 221-231.

18. WHO (1996) Permissible limits of heavy metals in soil and plants (Geneva: World Health Organization), Switzerland. 